\title{
Resources or Capabilities: A Study of Startup Emergence within Applied Research Universities in India
}

\author{
Kshitija Joshi ${ }^{1}$, Krishna Satyanarayana ${ }^{2}$, Muralidharan Loganathan ${ }^{3}$
}

1 Aditya Birla Group, India 0000-0003-2588-065X

2 Research Associate, Indian Institute of Management, Bangalore, India 560076 $\underline{0000-0001-9577-0558}$

3 Department of Management Studies, Indian Institute of Science, Bangalore, India 560012 Corresponding author muralidharanl@.gmail.com 0000-0001-5436-5791 


\begin{abstract}
:
Over the past decade, the Indian entrepreneurial ecosystem has witnessed a steep growth in the number of incubators within academic environments. While most of these have focused on provision of tangible and intangible resources, the understanding about processes and routines that transform these resources into capabilities, which ultimately translate into successful start-up emergence has been lacking. Based on the resource-based view and the dynamic capabilities approach and using the cases of two academic incubators in India (Indian Institute of Technology, Madras and National Chemical Laboratory, Pune), this paper analyses the pre-incubation level processes that have resulted in their enhanced opportunity recognition potential. This study adds to the literature in the area of dynamic capabilities in the context of academic incubation. The study has important implications for both incubation setups as well as policy makers.
\end{abstract}

Keywords: incubation, pre-incubation, startup, technology entrepreneurship, resources, entrepreneurial ecosystem, venture emergence 


\section{Introduction:}

The academic debate on whether or not universities need to engage in commercializing their technology is still far from being settled. While several researchers believe that commercial activity jeopardizes the conduct of open science and makes universities indistinguishable from firms (Mowery et al., 2001; Bok, 2003), others hold the position that involvement in commercialization activities and academic productivity reinforce each other positively (Azoulay et al., 2008). However, almost parallel to this academic debate are the success stories of several pioneering academic entrepreneurs who have been responsible for path-breaking new products and processes in a wide range of industries. In particular, in the area of bio-technology, participation from such star scientists has been the key to commercialization of several bioscience inventions (Bowen HK, 2015). Even in other highly specialized technology domains, academic entrepreneurs have been the key players in the processes of opportunity search and technology transfer within universities (Lockett et al., 2005).

And yet, the pathway from research labs to the establishment of ventures for such academic entrepreneurs is far from easy. The challenges pertaining to 'liability of newness' are especially pronounced for academic entrepreneurs as compared to their corporate counterparts (Vohra et al., 2004). Typically, university environments possess limited and specialized connections which constrain their ability to conceive and develop applications for their technologies. The social capital of such founders is also restricted to researchers and collaborators within other universities. Besides, they possess significant roadblocks at every critical juncture, starting right from the conceptualization of their initial idea extending until the final stage of establishing a commercial rent-generating firm (Zahra, et. al, 2007). Moreover, the conflicts of interest among the key stakeholders such as the university, the academic entrepreneur, the venture's management team and suppliers of finance (Vohra, et al., 2004) further add to the challenges encountered by academic entrepreneurs. Consequently, most new ideas that have a potential for commercialization often fail to see the light of the day. 
These difficulties have been recognized both by academia and governments resulting in the development of policies and institutional mechanisms supporting such venture creation. Establishment of academic incubators is one such significant measure. The incubator support primarily focuses on provision of resources, including material and networks for the nascent ventures. Yet, mere resource provisioning by itself cannot explain, why and how even with a similar set of resources, certain incubation setups are more adept at identifying start-up opportunities and then translating the same into successful ventures. In this paper using the context of academic environments, we discuss how resources alone are insufficient in the emergence of start-ups. Rather, it is the critical role of organizational processes that translate these resources into capabilities leading to such emergence. Accordingly, the focal research question addressed in the paper is 'what is the role of organizational processes in the translation of resources into capabilities and in what way it aids the startup emergence process'. Towards this end, using a case-based approach, we explore two applied research university environments in India that have historically seen a disproportionate proportion of new venture emergence in the burgeoning Indian entrepreneurial ecosystem for technology intensive startups.

This study makes the following important contributions to the existing literature. First we add to the literature on academic incubation, on how organizational processes and routines enable the transformation of resources into capabilities during the pre-incubation phase, resulting in enhancing the opportunity recognition potential. Secondly, this study distinguishes among two distinct types of academic environments itself viz. a government owned R\&D labs and a university, in terms of their resources and the relative processes and routines used by them in opportunity recognition for nascent entrepreneurs. Finally, we add to the literature on academic incubation in the context of India. Among emerging economies, China has been extensively studied (Tang et al., 2013; Chandra and Fealey, 2009; Scaramuzzi, 2002), but the same cannot be said about India. Given, the differences in the national systems of innovation among the two economies (Lundvall, 2007), results from China cannot be simply extrapolated to the context of India. This study brings out the need to study India separately in its own right. 
Following this introduction, in section 2 we present a glimpse of the Indian entrepreneurial ecosystem support, both its structure and growth over the course of the last two decades. Following this in Section 3, we present a brief literature review on technology intensive incubation and venture emergence phenomenon as applicable in our context and present gaps. Section 4 presents the case studies of the two types of academic incubators and Section 5 the analysis. The concluding section derives implications from the analysis for both researchers and policy makers.

\section{Indian Entrepreneurial Ecosystem:}

The Indian entrepreneurial ecosystem for technology intensive startups can be visualized through the structure proposed by Bala Subrahmanya (2017). In this structure we see the outer layer comprising the triple-helix (Etzkowitz, 2002), while the innermost core consists of the entrepreneurial motivations of prospective startups. The two layers surrounding the prospective startup includes the primary factors such as market, financing and other support systems. Secondary factors include the external environment mainly comprising the culture, media and also weather. Given this structure, we focus on two vital supporting elements of this start-up ecosystem: one - research labs that develop new technology and applications for the industry/market and two - entrepreneurial support organizations like incubators/accelerators that are supported both by the government and private sector. 


\section{Figure 1: Triple Helix Model of the Indian Entrepreneurial Ecosystem}

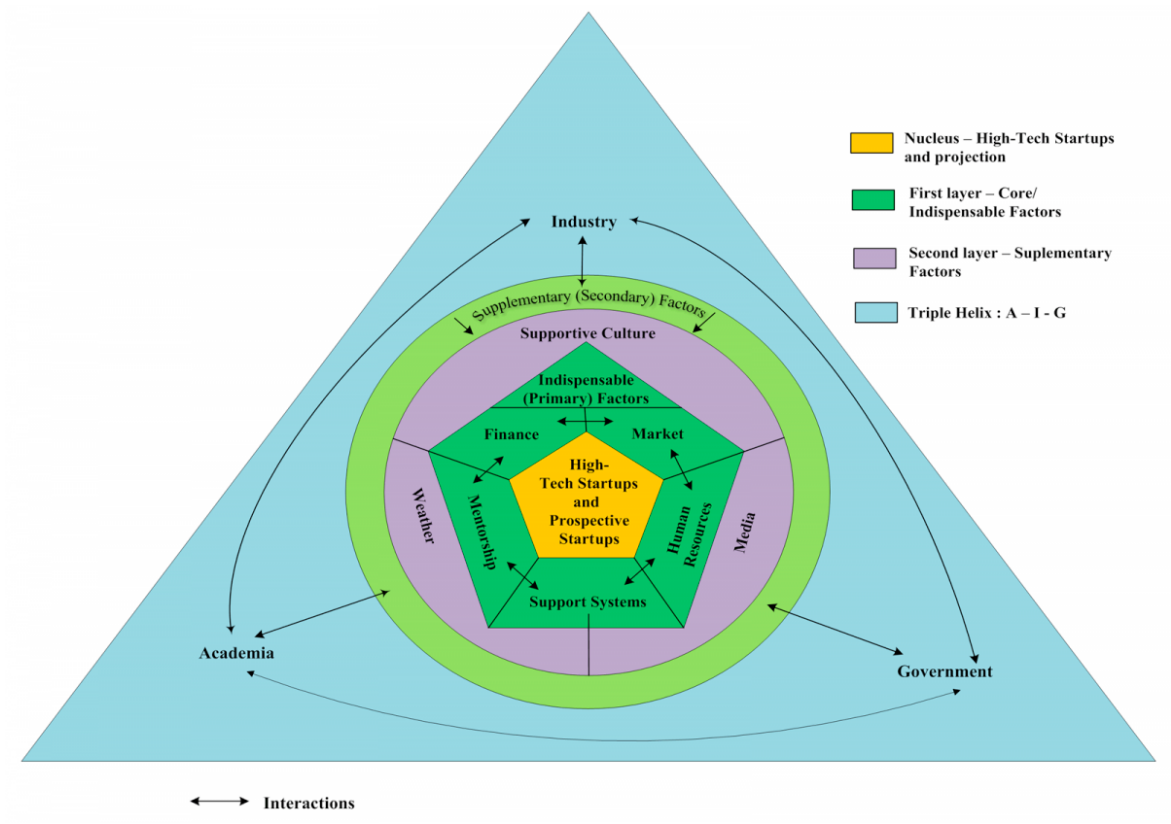

Source: Bala Subrahmanya (2017)

\section{Growth of entrepreneurial support organizations in India:}

The history of entrepreneurial supporting organizations for technology ventures can be traced back to the formation of the National Science and Technology Entrepreneurship Development Board (NSTEDB) under the aegis of Department of Science and Technology (DST) in 1982. Largely, the policy focus has been the creation of newer mechanisms for supporting science-led entrepreneurship (DST, 2013). Such policy intent has been institutionalized through various programs under the Department of Science and Technology such as Science and Technology Led Entrepreneurship and Innovation Promotion (DST, 2016).

Over the course of the last three decades these programs have seen rapid growth irrespective of the economic or political climate in the country. As of 2017, there were four broad institutional mechanisms under NSTEDB for promoting academic entrepreneurship. This includes 
1. Innovation - Science and Technology based Entrepreneurship Development (i-STED), established with the objective to identify and address challenges and issues in an area/industry/cluster through technological interventions and innovative approaches and adopting an entrepreneurial approach to generate socio-economic development.

2. National Initiative For Developing And Harnessing Innovations (NIDHI), established with the objective to nurture start-ups through scouting, supporting and scaling of innovations.

3. Science \& Technology Entrepreneurship Park (STEP) established with the objective to create an atmosphere for innovation and entrepreneurship, for active interaction between academic institutions and industries for sharing ideas, knowledge, experience and facilities for the development of new technologies and their rapid transfer to the end user.

4. Technology Business Incubators (TBI) established with the objectives to creating technology based new enterprises, creating value added jobs \& services and facilitating technology transfer from research universities.

Thus each of these mechanisms have specific objectives that touch some aspect of entrepreneurship, and innovation development support. Among these objectives creation of technology/innovation based new enterprises is common across (NSTEDB, 2017). STEP is the oldest mechanism of these back in 1982 and there are currently 15 STEPs across the country.

In particular, the TBIs have become popular and seen rapid growth over the recent years. As of 2014 there were more than 120 incubators specialized in diverse industry sectors or technology arenas across the country (MSME, 2013). DST provides grants for both capital and operational expenditure and seed support for startups through these incubators for both the establishment and operations of startups over a period ranging from 3 to 5 years. Many of these TBIs are associated with and hosted in higher education and research universities providing ample opportunity for science and technology-based product development. Mechanisms other than TBIs are relatively new and have been promoted since 2014 actively. 
The Ministry of Science and Technology runs a network of laboratories that conduct scientific and technological research across the country. Most of these research laboratories also perform the function of higher education in addition to research. Thus, these research laboratories and higher education universities provide a seed bed for emergence of new technology enterprises and have both the responsibility and policy support to nurture these enterprises.

These academic universities, incubators hold over 450 patents and copyrights (NSTEDB Report, 2014). They have incubated about 1000 companies out of which about $28 \%$ have graduated successfully out of these incubators (Venture, Intelligence, 2014). As of 2014, the companies that have been incubated here have generated a turnover of over 219 MN USD (NSTEDB Report, 2014). It has been estimated that the incubatee and graduated companies have together generated an employment for about 32,000 people (DST, 2016). Thus, there is no doubt that if used appropriately, these incubators hold the promise for innovation and startup emergence.

Given this background, we now present a few details about the profile of incubators in India. 


\section{Figure 2: Location of Academic Incubators}

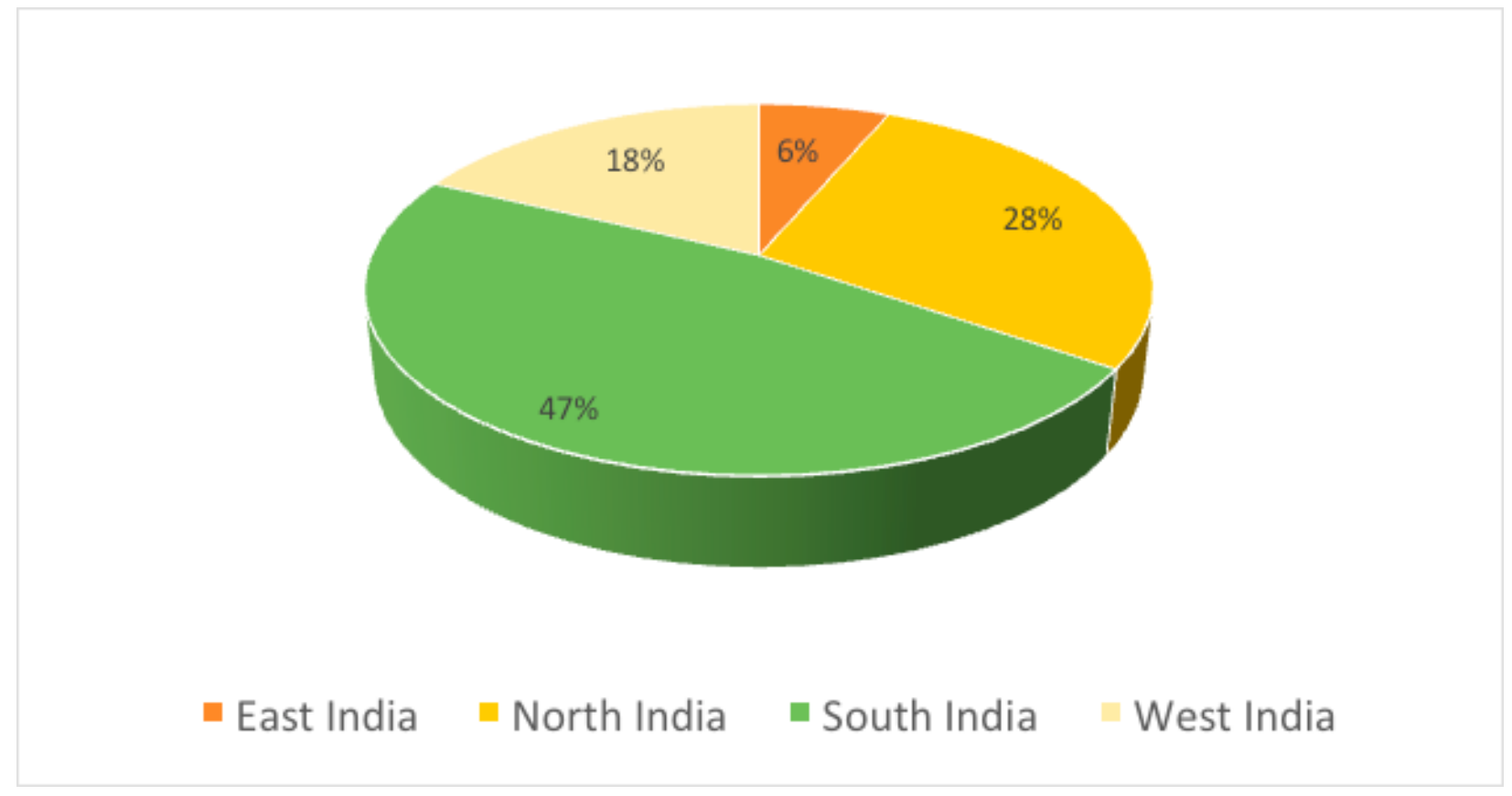

Source: NSTEDB Report, 2014

From Figure 2, it may be seen that about $47 \%$ of the incubators are located in South India, 28\% of them in North India, 18\% in West India and just $6 \%$ in East India. This is fairly consistent with the rest of the elements of the entrepreneurial ecosystem, such as venture capital firms, high technology start-ups and multinational corporations (Joshi and Satyanarayana, 2014). In particular, the presence of 'critical mass', is the principal factor responsible for the concentration of incubators in South and West India (Joshi, 2015). Bangalore, Hyderabad Chennai, Mumbai and Pune the three important startup hubs of India are located in South India. About $74 \%$ of all start-ups and $83 \%$ of all VC funds are located here. About $84 \%$ of all technology exports (IT and ITeS sectors) emerge from these five cities.

Figure 3 reveals that about $77 \%$ of the incubators are hosted in universities and $7 \%$ in Research Laboratories. $6 \%$ each are hosted in Technology parks and Industry associations. Thus, 
university environments dominate the locations for incubators followed by research laboratories. Incubators based in these two locations have been selected by us for our analysis.

\section{Figure 3: Type of Host Institution for incubators}

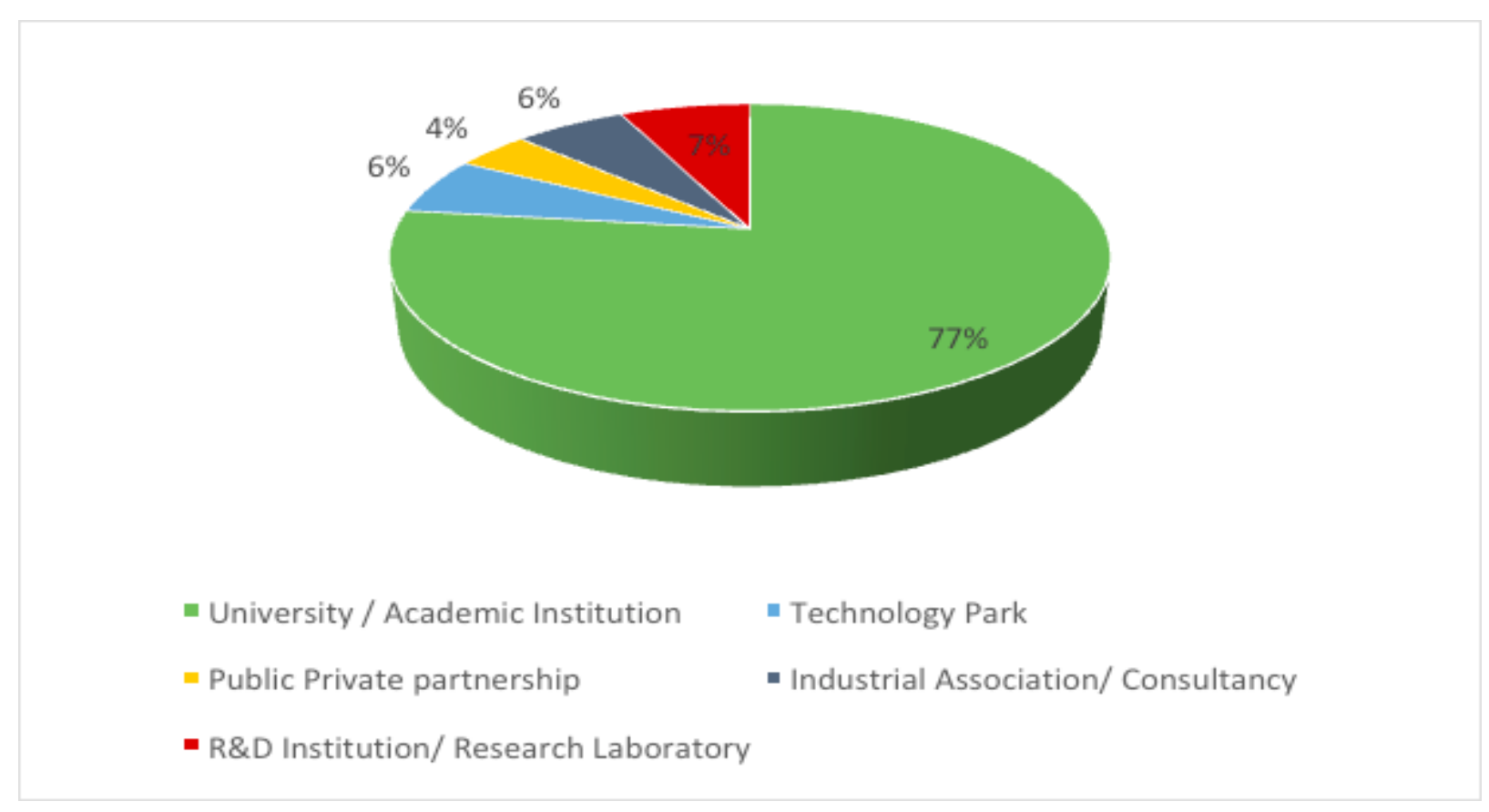

Source: NSTEDB Report , 2014

Table 1 presents the sector focus of the academic incubators. Information Technology, Electronics Healthcare, Bio-technology and Clean Energy are seen to be as major focus areas for incubators. This also fits into the existing schema of start-up ecosystem - wherein about $63 \%$ of the start-ups are focussed on the IT domains (Joshi, 2015; Satyanarayana, 2017). 
Table 1: Sector-Focus of Incubators

\begin{tabular}{|c|c|}
\hline Sector Focus & Proportion of Incubators \\
\hline Information Technology (including Mobile Applications) & $16 \%$ \\
\hline Hardware, Electronics, Embedded Technology & $13 \%$ \\
\hline Energy (Clean Technology) & $13 \%$ \\
\hline Bio -Technology (Food and Agriculture) & $12 \%$ \\
\hline Healthcare (Product-based) & $11 \%$ \\
\hline Manufacturing (Engineering based) & $9 \%$ \\
\hline Rural Technology & $7 \%$ \\
\hline Agri-business & $6 \%$ \\
\hline Nano-Technology & $6 \%$ \\
\hline Others & $8 \%$ \\
\hline
\end{tabular}

Source: NSTEDB Report, 2014

Despite the progress made, the viability of a large number of incubators in India still remains questionable. Most of the academic incubators have focussed just on provision of physical resources like infrastructure. True to their stated objectives, in addition to physical infrastructure, incubators need to provide enhanced services like mentoring and access to financial institutions, 
business networks and investors. TBIs that provide a technology entrepreneur access to the required machines, instruments and apparatus to test products, further manufacture products on a pilot scale and then expand, are yet to gain prominence even with government support (MSME, 2013).

Start-ups may fail to take full advantage of the incubator's resources. This could be owing to a number of reasons. Entrepreneurs are averse to using incubator's resources when they find the same to be of poor quality. E.g., entrepreneurs might look for mentors with experience, whereas the incubator fails to provide them with the same, similarly, entrepreneurs might not be engaged in networking activities if they believe the incubator's networks to be under- developed. Further incubators may not sufficiently take the needs of the incubated start-ups into account, which results in a mismatch between the resources provided by incubators and the resources needed by start-ups. Also, the incubator's services could possibly be too generic and not tailored to the specific needs of individual start-ups. It could also be possible that entrepreneurs fail to recognize the gaps in their own resource base. Hence, they are unable to realize the value of the incubator's resources. Incubators often fail to distinguish between the requirements of a start-up during its emergence and growth phases, and the fact that interventions for venture support need to be different (Löfsten and Lindelöf, 2002).

\section{Background literature:}

\section{Resources in the context of academic startups}

Business incubators play a critical role in bridging the gap between academic start-ups and the commercial world. The resource-based view (RBV) envisages firms to comprise resources that are valuable, rare, imperfectly imitable, and non-substitutable (Barney, 1991). Such resources, capabilities, and routines enable firms to execute strategies that directly impact the firm

performance and result in competitive advantage (Lucas and Goh, 2009; Solesvik and Westhead, 2010). The prime objective of incubators is promoting technology transfer and diffusion of 
products providing a supportive and entrepreneurial environment for technology-based start-ups that ultimately translates into increased survival rates (Aerts, et al, 2007). According to the RBV, incubators have the potential to complement the resource base of start-ups and to facilitate their survival and growth (Weele et al., 2017). Incubators are aimed at supplementing the existing pool of knowledge possessed by academic entrepreneurs, by providing the resource-base necessary for supporting their development in early and critical stages (Somsuk et al., 2011).

Among others, the most important contribution of incubators is that of aiding the process of opportunity recognition itself. Intellectual Capital and Social Capital have been identified as two significant contributors to the process of opportunity recognition (Rodriquez et al., 2010) Typically, although the academic entrepreneurs possess abundant intellectual capital in the form of domain knowledge, they are often unaware about the economic valuation of such knowledge. This is because knowledge is characterized by huge information asymmetry with different economic agents assigning different economic valuation to the same knowledge. Moreover, most knowledge is often tacit in nature and hence there is a significant effort involved in transforming this knowledge into a business opportunity (Ács et al., 2009; Hayter, 2015).

Social Capital is the other vital resource in the opportunity recognition process (Rodiquez et al., 2010). Both social capital theory and network theory believe that people with a larger network of social and professional contacts are invariably exposed to a wider range of ideas and opportunities (Cooper and Yin, 2005). Undoubtedly the most valuable social network in the field of entrepreneurship is one that comprises other entrepreneurs and the latter's own social networks. Networking with other entrepreneurs, or business angels, aids in enhancing the opportunity recognition capacity. From the network theory perspective, social networks can provide critical information, ideas and resources for starting a new firm (Larson and Starr, 1993). Moreover, not strong but weak ties are known to aid opportunity recognition and entrepreneurship (Arenius and De Clercq, 2005). For academic entrepreneurs in particular, alumni networks are one of the most significant sources of such weak ties. Alumni act as experiential role models, especially those with experience of having built businesses of their own (Patton et al., 2009). In fact, the alumni foundation of the University of Wisconsin marketed 
patents derived from academic research to industry and financed faculty research projects with these funds. These funds enabled Wisconsin to become a major research center in biology (Etzcowitz, 2001).

Along with intellectual and social capital, human capital is the other most important resource for any start-up. In fact, the quality of the entrepreneurial-managerial group is one of the prime factors that aid the opportunity recognition process and later impacts growth and success of new business ventures (Heirman and Clarysse, 2004; Mustar et al., 2006). Technology-based ventures, especially in academic environments are more likely founded by teams rather than single entrepreneurs (Visintin and Pittino, 2014). Joint presence of academic and non-academic members in a startup is an important dimension that has been found to enhance the integration of the 'scientific' and 'economic' conception of science and is thus related to better start-up performance (Visintin and Pittino, 2014). As such, mixed teams are likely to stimulate brainstorming that encourages learning and problem solving (Gibson and Vermeulen, 2003). Such discussions are valuable for academic startups engaged in highly uncertain tasks aimed at the transformation of nascent technologies and prototypes into viable products. One of the vital element of human capital relates to the erstwhile founding experience of the academic entrepreneur. Entrepreneurs are more likely to discover opportunities related to their prior knowledge (Shane, 2000). Conceivably, serial entrepreneurs are particularly good at opportunity recognition (McGrath and MacMillan, 2000; Westhead et al., 2009). While the start-ups within academic environments are likely to possess abundant intellectual capital, they are laggards with regards to their social and human capital elements. By complementing the these academic start-ups with such resources, the academic incubators precisely bridge this gap.

Along with the above other concrete and tangible resources are also vital. Physical capital includes the firm's plant and equipment, its location, and its access to raw materials (Barney, 1991). Startups often lack economies of scale to build up physical capital of their own. Incubators can bridge this gap by providing shared office space and facilities such as equipment, 
meeting rooms or a reception (Bergek and Norrman, 2008) and also specialized physical capital, such as university libraries and laboratories (Mian, 1997).

Financial capital refers to different monetary resources available for the discovery and exploitation of the venture idea (Barney, 1991). Start-ups usually need seed capital for the research and development of their proposed products at the pre-sales stage (Westhead and Storey, 1997). At the same time, funders view startups as high risk investments owing to their nascency and moreover, the information asymmetries associated with their technology (Carpenter and Petersen, 2002; Gompers and Lerner, 2001). Therefore, start-ups often struggle to attract the necessary financial capital. Incubators can contribute to the financial capital of start-ups by providing seed capital in exchange for equity, or they can help start-ups in an indirect manner to find external investments by connecting startups to external funding sources (Costa-David et al., 2002).

Incubators can also contribute to the start-up's business knowledge by providing training programs or coaching by experienced entrepreneurs in the incubator (Rice, 2002). These sessions can provide knowledge that is tailored to the start-up's circumstances, as coaches can engage in an ongoing dialogue with the entrepreneur and provide specific feedback (Rotger et al., 2012). University affiliated incubators may also add to a start- up's technological knowledge base, as the proximity to university laboratories and research groups offers easier access to technological knowledge, thereby facilitating the technology transfer process (Etzkowitz, 2002; Rubin et al., 2015).

Legitimacy refers to an organization's "right to exist and perform an activity in a certain way" (Bruton et al., 2010). Legitimacy is often the pre-condition for organizations to attract other resources, such as social and financial capital (Bruton et al., 2010; Shane and Cable, 2002). In general, start-ups suffer from a lack of legitimacy as they do not have a track record or an established network ( Bruton et al., 2010). However, being associated with or selected by an incubator that has a proven track record of supporting successful businesses, or that is itself 
affiliated with a renowned university by itself might be an important mechanism for gaining legitimacy for startups (Bøllingtoft and Ulhøi, 2005; McAdam and McAdam, 2008).

\section{Dynamic Capabilities Approach to Incubators}

So far, we have used the RBV to explain how incubators complement and reinforce the resources of the academic start-up firm. However, this approach is largely static and fails to explain how firms manage to convert their resources into capabilities. Resources are stocks of available factors a firm owns or controls (Amit and Schoemaker, 1993), whereas capabilities denote the firm's capacity to deploy its resources for a desired end result (Zahra et al., 2007). Many researchers such as Teece et al. (1997) believe the RBV to be conceptually vague and tautological and fails to delve deeper into the processes that enable firms to convert their resources into competitive advantage. Not resources alone, but dynamic capabilities of the firm that are embedded in its processes enable managers to alter their resource base, integrate them and reconfigure them to generate new value-creating strategies. Such dynamic capabilities are the drivers behind creation, evolution and recombination of other resources into new sources of competitive advantage (Teece et al., 1997). Zahra et al. (2007) point that that not just resources alone, but the 'knowledge-conversion capabilities' of the start-ups is what determines their abilities to encounter competition.

In the context of academic start-ups, cultures, incentives, and systems (Moray and Clarysse, 2005) of the parent university are passed on to these spin-offs, possibly determining their knowledge base and resultant knowledge-conversion capabilities. The interplay between the knowledge-pool residing in a start-up and the knowledge gained through learning from customers, suppliers, and other companies can lead to innovations that generate new business concepts, processes and models (Cook and Brown, 1999). Knowledge conversion capability has three components. The first is "conceptualization and visioning" which means visualizing potential uses and applications for the new technology ( Leonard-Barton, 1995). The second is "configuration and design" which involves developing working and functional prototypes that 
transform this knowledge into new products (Leonard-Barton, 1995; Ulrich and Eppinger, 2000). The third is "embodiment and integration" which relates to a firm's ability to assimilate varied knowledge from different sources (Kogut and Zander, 1992; Ulrich and Eppinger, 2000; Alavi and Liedner, 2001; Zahra and Nielsen, 2002) and convert its technology to marketable products. On similar lines, Eisenhardt and Martin, (2000) state that dynamic capabilities comprise three specific organizational and strategic processes such as product development, alliancing and strategic decision making. These help the firms in manipulating resources and in general converting them into value-creating strategies.

University capabilities are routines to promote entrepreneurial processes within the university and refer to the ability of the university organization to facilitate the start-up formation process. The university processes that promote startups can take several forms such as - professors allowed to use their sabbatical leave in the start-up or the university management legitimizing the start-up project within the university set-up or allowing for the inclusion of external industry experience in the project team and board or forming joint venture between university and industry partner or facilitating support from the Technology Transfer Office to work on ownership and IPR agreements (Rasmussen and Borch, 2010). Such micro-level processes within the university play a critical role in the conversion of 'static' resources into dynamic capabilities.

Although the internal and external resources of the academic start-up and the conducive processes of the firm are vital; the influence of the local ecosystem on the emergence of academic startups cannot be ignored. The characteristics of the industries present in the local context can also determine significant business opportunities (Klepper, 2007). The existence of companies that operate in the same or related sectors promotes the natural exchange of ideas through formal and informal networks among organizations. The presence of 'critical mass' of firms belonging to the same industry are conducive to the academic start-up culture (Joshi and Satyanarayana, 2014). These firms can be conduits of technology transfer by acting as both mentors as well as potential customers. In fact, Friedman and Silberman (2003) found that universities in locations that are characterized by a relatively high concentration of technology 
firms generate more licenses and license income (Fini et al., 2011). Another important element of this local ecosystem are the venture capitalists and typically venture capitalists focused on early-stage investments tend to be concentrated in same geographic locations as incubators (Joshi, 2015; Joshi and Satyanarayana, 2014).

\section{Research Gaps}

Based on the above survey of literature, we identify the following research gaps. Although there are several studies in the arena of academic spin-offs and incubation, the specific processes by which the universities help in the opportunity recognition process have not been adequately analysed. The mechanisms through which the academic incubators achieve specific mission objectives are often context-specific (Mian et al., 2016). The examination of micro level aspects of emergence mechanisms within academic universities that result in these startups feeding into the academic incubators are still not adequately represented in literature. Our study attempts to address this research gap. The studies that exist, investigate and compare these processes mainly across diverse universities. However, even within the academic environments, there exist significant differences among these processes between government owned R\&D labs and universities. These differences if any need to be looked into rigorously.

In the Indian context, incubation phenomenon has been sparsely analysed. Given the huge spurt in incubators over the recent past and the increasing government support for the same, it needs to be analysed in detail. Moreover, incubators located within science parks have been well-studied in the Chinese context. However, India and China significantly differ in terms of their cultures, institutional mechanisms, national systems of innovation and moreover in attitudes towards risk (Huang and Khanna, 2003). Hence, we believe that the results from China cannot be simply extrapolated to India and that India needs to be assessed separately in its own right. 


\section{Case Studies of pre-incubation support for venture emergence in India}

\section{Background}

In India, the states of Maharashtra and Tamil Nadu are significant contributors to India's GDP. Although, these states host just $15 \%$ of the total Indian population, their contribution to India's GDP is greater than $28 \%\left(\mathrm{RBI}_{\mathrm{a}}, 2017\right)$. Further, they account for about $25 \%$ of the aggregate tax revenue and are destinations for more than $40 \%$ of the total FDI received in India $\left(\mathrm{RBI}_{\mathrm{b}}, 2017\right)$. The socio-economic infrastructure is reasonably well-developed here, as can be observed from the breadth and depth of industrialization and higher education universities in these states. Further the major cities in both the states have a burgeoning manufacturing and services sector. Industrial clusters in Information Technology, manufacturing particularly automobile and pharmaceutical sectors are well developed across the cities of Mumbai, Pune, Chennai, Coimbatore in these two states (RBI, 2017).

In these states, the entrepreneurial ecosystem support through incubators has been particularly focussed on the Information and Communication Technologies (ICT) sector. However, the expertise that is required to commercialize intellectual property emerging from science and technology research universities is still quite distinct from the ICT sector. For the emergence of science based ventures from research universities there has to be a large scientific knowledge base and infrastructure supporting the various pathways of product development and venture creation. We believe the mechanisms of emergence of startups in India, can be explored by taking cases of entrepreneurial ecosystems in two applied science universities located in the states of Maharashtra and Tamil Nadu. Both these universities have a legacy of research and are situated in two vibrant industrial clusters or cities. Considering their research output and infrastructure and their history of supporting entrepreneurship, we chose the National Chemical 
Laboratory (NCL) in Pune (Maharashtra) and Indian Institute of Technology Madras (Tamil Nadu) for our study.

\section{Case of research driven venture creation at NCL Pune}

National Chemical Laboratory, Pune was established in 1950, under the Council for Scientific and Industrial Research of the government as a research, development and consulting organization. Its mission and objectives give prominence to its relevance to the Indian chemical and life sciences related industries. Historically NCL has been known for its excellent infrastructure and academic outcomes in terms of number of PhDs graduating and its publications and patent portfolio. The incubator called Venture Center in NCL was established in 2006 with the core purpose declared as "nucleate and nurture technology and knowledge-based enterprises for India by leveraging the scientific and engineering competencies of the institutions in the region". This core purpose necessitates surfacing commercial venture opportunities as a potential outcome of the applied research that the university is doing. Since inception the nature and scope of services provided by the incubator has increased to cover technical, financial and strategic needs of aspiring entrepreneurs and startups.

On the technical front, the infrastructure shared across NCL and the Venture Center, includes a broad set of facilities that can help develop, and test innovations in a range of applied science related to biology, materials and chemistry. Such technical infrastructure is given on subsidized rent to entrepreneurs. Further there are structured programs for "translating scientific competencies into commercial products". These include the Ignition and Kickstart programs, Lab2Mkt program and the Proof Of Concept (POC) fund.

The Ignition and Kickstart programs are positioned to jump start technology projects that have significant potential for becoming ventures. These programs offer specific support in opportunity recognition and reducing technology uncertainties through specific interventions. These interventions include developing proof of concepts and sourcing missing technology 
components. The programs also mediate partnerships for the venture, in addition to market research and intellectual property strategy help. Such help is delivered through the inhouse mentors as well as the external mentor network for a nominal fee.

The Lab2Mkt program is a three stage process that is aimed at building ventures through technology commercialization. As the incubator takes equity stake in the startup that is going through the program, there is an institutional commitment to make the startup succeed, and reduce its risks and progress to its next lifecycle stage. The program itself begins in stage one with market research, and strategy / business model development, followed by a resource provisioning stage for product development which includes both infrastructure and capital, and in the final stages of the program the newly emerged venture develops a business plan and begins raising further growth capital. The nature of engagements facilitated by the program cover customer trials, intellectual property transactions including technology commercialization, risk mitigation and financing. Lab2Mkt brings together expertise for the startup from intellectual property to business planning through a variety of network partners of the incubator across public and private sectors. More than half of the portfolio of the incubator are graduates from this program.

The POC Fund allows for development of commercial products over a period of 12 months, through structured projects that are fully funded through the program, utilizing both the expertise and infrastructure available at the university. Such programs have provided the necessary impetus in opportunity recognition and building awareness to potential entrepreneurs on the nature of risks and effort needed for both product development and venture development at different life cycle stages of the startups. The Venture Center at NCL regularly organizes government and industry engagements that exposes potential entrepreneurs and incubatees to various opportunities for national and international funding and grants from governments and industrial consulting and projects. Some of these programs include driving innovation development activities in select areas that are of national importance and are accordingly policy focus areas of the government. 
The Venture Center tracks the progression of technology development through evaluation of startup's Technology Readiness Level and as of August 2018, 22\% of the ventures have progressed to level 3 (prototype technology developed, tested and demonstrated at pilot scale) or above, while a vast majority of ventures remain at early stages of technology development. This further illustrates the need for pre-incubation programs supported by the Venture Center. About $88 \%$ of the ventures are in the fields of Life science, physical and chemical sciences fields, owing to the expertise and infrastructure at the university developed since inception. Further the NCL institutional connection from the large base of scientific staff, students and technology which accounts for about $20 \%$ of all ventures in the Venture Center, indicating the continuity of research outcomes or expertise to commercial product development and pursuing entrepreneurial venturing (NCL, 2018).

\section{Case of student driven venture creation at Indian Institute of Technology, Madras}

IIT Madras has a sprawling 600 acre campus that houses more than 15 departments across various disciplines. It has been consistently ranked high on national ratings for academic and research excellence. Innovation and entrepreneurship support at IIT Madras is supported by four organizations that work in a loosely coordinated manner. These include India's first university-driven Research Park (IITMRP), a set of incubators, student driven entrepreneurship centers like the Center for Innovation (CFI) and the Entrepreneurship Cell that includes the pre-incubation support program under NIRMAAN (a sanskrit word meaning “creation") and a highly engaged alumni entrepreneurship forum called the IIT Madras Entrepreneurship Forum (IITMEF). For our analysis we take a closer look at the pre-incubation support from CFI and NIRMAAN.

Center for Innovation (CFI) is a student run lab that was originally a large central workshop with an endowment from 1981 Alumni and a matching grant from the institute. It is set in the building 
that houses the Central Workshop, right in the middle of the academic zone in the beautiful IIT Madras Campus. CFI was started in 2008 with an objective to be a forum for creative output of the budding engineers of IIT Madras. It provides students the necessary platform for realizing their ideas. A great workspace, a comprehensive inventory, ample guidance from faculty and senior-students and the zeal and passion of the CFI team make CFI a gifted asset for IIT Madras students. And over time, CFI has successfully evolved into a hub which encourages thinking and provokes students to generate novel ideas making it truly the "centre" for innovation. Over the ten years since its inception, CFI has enabled the students to explore entrepreneurship as a career choice while parallel completing their bachelors' degree. All students of IIT Madras can optionally enroll into this Student Lab, and volunteer to be part of an ongoing project, or seek partners for their own idea. Based on the proposer's individual skills, novelty of the idea, and acceptance of participation by other CFI student members, teams get formed to convert this entrepreneurial idea into a working prototype.

CFI is essentially a sandbox where students come and work on their ideas for development. It was started to bring together several student hostel centered clubs to experiment with their ideas. A part of students' contribution diverted to CFI for its sustenance to experiment with students' ideas. In CFI, senior students evaluate the projects of junior students. On average, about 1200 students forming about 300 to 400 teams operate out of CFI. This is purely a student centric entity and a tech playground for them. The purpose of the center is represented in its tag line "walk in with an idea and walk out with a product". Therefore, their business acumen is hardly tested here. Here, faculty members play only an advisory role. Apart from that there is no external intervention or financial support from either faculty or mentors at IIT Madras. Short-listed projects are encouraged to move to NIRMAAN, a pre-incubation cell (DST, 2018).

The ideas that manage to make progress along the path to product creation serve as a pipeline to NIRMAAN, the pre-incubation cell at IIT Madras. NIRMAAN is a unique organization created for the students of IIT Madras that helps students to create a startup with their idea/prototype. In NIRMAAN, every short-listed CFI project gets a grant upto USD 7500 as seed money, to encourage the experimentation of the student idea generated projects which have been evaluated 
and short-listed by the IITM faculty and as well as external experts. NIRMAAN's structured 4 stage approach includes identification and validation of the problem followed by a critical stage of acquiring interest from a lead customer for the product/service.

The participants in NIRMAAN are typically 3rd year students moving into their 4th year of a bachelor's degree in engineering. Such students are allowed to have deferred placements (for 2 years) to encourage risk-taking and ensure the students do not lose out on campus placement opportunities. About 30 to 40 out of the total of 300 to 400 projects teams from CFI graduate into NIRMAAN. However, there is a provision to directly move into NIRMAAN by-passing CFI, if a student has a viable idea for technology development, nurtured in a faculty lab at IITM. In NIRMAAN, IITM alumni and 3 to 4 IITM faculty members play a role. The family background of students is assessed and their ability to understand the markets also plays a crucial role in assessing their risk-taking potential. (DST, 2018).

Further, as an incentive, those ideas that are able to successfully leverage this support and show tangible economic progress (measured in terms of acquiring early customers, acquiring seed/follow-on funding etc.) can convert their time and effort spent into an elective that will be formally certified by IIT Madras. This program structure enables students to focus on innovation, experience entrepreneurship and think beyond placements. A small portion of students' annual fees serve as the mechanism to sustain and operate the CFI and NIRMAAN programs at IIT Madras.

It is found that on an average, about $10 \%$ of the ideas supported by NIRMAAN actually make further progress and result in creation of formal startups. NIRMAAN finally feeds into the TBIs of IITM in the Research Park. The graduated projects with successful proof of concept and prototypes coupled with a business plan are encouraged to form a start-up. The Research Park based TBIs of IITM focus on commercialization of innovation for venture creation. The philosophy is that an innovation must have a commercial value and it must generate revenue at 
the earliest. Generally, a venture with a team of founders is preferred over those started by single-founders.

The stage where a start-up is independent of the TBI support is a signal for graduation. At this stage, they would have started generating revenue to take care of the costs, obtained the university's follow-on funding, and market stability. As of 2017, IITM Research Park based TBIs housed about 130 incubatees comprising 65 from NIRMAAN, 45 spin-offs from IIM faculty, and 30 from external groups, which got linked to the R\&D ecosystem of IITM. As of 2017, the Research Park graduated about 40 start-ups (DST, 2018) .

IIT Madras hosts a bunch of incubators like Rural Technology Business Incubator, and Villgro that were sponsored originally by the Department of Science and Technology, more recently Department of Biotechnology has sponsored two incubators as well. Many of these incubators are housed in the first of its kind research park adjacent to the university.

The IIT M Research Park was established with support from Ministry of Human Resource Development, the institute's internal fund sources including alumni endowment and credit from banks. The core purpose of the research park is to provide an environment to support technology and innovation driven venture development, commercializing research and collaborating with the university. The research park tenants are mostly industry research centers, but $15 \%$ is set aside exclusively for incubatees both of the research park and its sister incubators.

Intangibles and within that intellectual property related motivation underlies the establishment of the research park. One of the background research identified that a significant fraction of patents filed from Silicon Valley had an Indian origin inventor associated, of which a major fraction was an IIT alumni. This led to the conclusion that if such opportunities are possible in the Silicon Valley with the IIT graduates, there exists an opportunity to create those opportunities in India as well. Encouraged by the results obtained from the IITM experience, the Startup India Action 
Plan of Government of India has proposed to set up seven new Research Parks modeled on the Research Park of IIT Madras (DIPP, 2016).

\section{Analysis of the cases}

We will examine the two selected universities and their role in building dynamic capabilities of the emerging entrepreneurial ventures using the classic framework of Chan and Lau (2005). This framework is broad enough to cover the provisioning of resources and the mediation opportunities that the ecosystem could support. For our analysis we do not distinguish the various pre-incubation programs that are available at the universities. Accordingly, NIRMAAN and CFI resources are taken together in the IITM case and Lab2Mkt program along with its pre-cursor support programs are taken together in the NCL Pune case. 
Table 2: Assessment criteria and indicators adopted for the pre-incubation study

\begin{tabular}{|l|l|}
\hline Assessment Criteria* & Indicators used $* *$ \\
\hline Sharing and Pooling of resources & $\begin{array}{l}\text { Common Infrastructure facilities, } \\
\text { appropriation of intellectual property, expert } \\
\text { and learner level human capital availability }\end{array}$ \\
\hline $\begin{array}{l}\text { Mentoring/Coaching/Consulting/Counselli } \\
\text { ng services }\end{array}$ & Services pooled by the institutional ecosystem \\
\hline Image, Reputation & Institutional culture \\
\hline $\begin{array}{l}\text { Clustering, Networking and Proximity } \\
\text { related advantages }\end{array}$ & $\begin{array}{l}\text { Number and strength of partnerships, Board } \\
\text { Experience, Complimentary value added } \\
\text { services, partner/investor connects }\end{array}$ \\
\hline Costs and Financial Capital & $\begin{array}{l}\text { Availability of investors and investment } \\
\text { capital, Strength of company } \\
\text { formation/emergence at region level }\end{array}$ \\
\hline
\end{tabular}

*Source: Chan and Lau (2005)

** Comment by authors 
Table 3: Indicators for the sample universities NCL and IITM

\begin{tabular}{|c|c|}
\hline Indicators & Institutional Analysis \\
\hline $\begin{array}{l}\text { Common } \\
\text { Infrastructure } \\
\text { facilities, } \\
\text { appropriation of } \\
\text { intellectual } \\
\text { property, expert } \\
\text { and learner } \\
\text { level human } \\
\text { capital } \\
\text { availability }\end{array}$ & $\begin{array}{l}\text { NCL Pune: Technical resources provided by NCL Pune for nascent } \\
\text { startups include intellectual property, and infrastructure. Much of the } \\
\text { infrastructure that are high capital expenses for early stage startups is } \\
\text { shared among startups on a standard usage and the charges are subsidized } \\
\text { as well. These equipment lists are regularly updated and published on the } \\
\text { website. } \\
\text { Human capital in NCL is both resident and visiting faculty and researchers } \\
\text { along with the leadership team on the board of the incubator. } \\
\text { NCL is fairly specialized in different areas of life sciences, physical and } \\
\text { chemical sciences and to some extent in mathematical and computational } \\
\text { areas as related to above sciences. Hence most of the startups that seek } \\
\text { venture center support also tend to be very specialized and niche. }\end{array}$ \\
\hline
\end{tabular}




\begin{tabular}{|c|c|}
\hline & $\begin{array}{l}\text { With } 16 \text { departments and more than } 100 \text { laboratories IIT M has the critical } \\
\text { mass of base infrastructure to pursue research in various specialized areas. } \\
\text { Such support for development caters to various stages of development } \\
\text { starting with conceptualization all the way to testing the products in } \\
\text { various fields and sectors. }\end{array}$ \\
\hline \multirow[t]{2}{*}{$\begin{array}{l}\text { Services pooled } \\
\text { by the } \\
\text { university } \\
\text { ecosystem }\end{array}$} & $\begin{array}{l}\text { NCL Pune: The pre-incubation support is delivered through the POC } \\
\text { (product development), Kick start (business planning) and ignition } \\
\text { (technology strategy including IP transfer) programs, while the } \\
\text { entrepreneur is still evaluating venture creation. } \\
\text { The resident intellectual property licensing office is well versed in the } \\
\text { domain as well as the nature of transactions on IP. Such transactions are } \\
\text { customized depending on the needs of startups. As can be seen from the } \\
\text { readiness level of technology that are being commercialized from the } \\
\text { Venture Center, most of them are in proof of concept or pilot stage with } \\
\text { about } 1 \text { in } 10 \text { moving to the customer test stage. These numbers should not } \\
\text { be considered as meagre, especially in the bio-technology domain, as the } \\
\text { market entry process for such products is long and highly regulated. }\end{array}$ \\
\hline & $\begin{array}{l}\text { IIT M: Ideation to pre-incubation support is provided by CFI. } \\
\text { Rudimentary support in terms of infrastructure, IP, finances, mentoring etc } \\
\text { is provided to student teams at this stage. This program is meant to test the } \\
\text { strength of the idea and the conviction of a group of people to come and } \\
\text { work together to create a new product/offering. } \\
\text { The ones who survive the test of time and perseverance and the ones that } \\
\text { are able to show a tangible outcome based on their initial plans become } \\
\text { candidates for the pre-incubation program - NIRMAAN } \\
\text { Pre-incubation to prototype creation/startup creation support is provided } \\
\text { by NIRMAAN }\end{array}$ \\
\hline
\end{tabular}




\begin{tabular}{|c|c|}
\hline & $\begin{array}{l}\text { Formal and structured support on all functional aspects (finance, } \\
\text { infrastructure, mentoring, access to networks, early adopters) of an } \\
\text { enterprise is extended to selected teams who just have a clearly articulated } \\
\text { entrepreneurial idea. } \\
\text { With all the above support, and time, the team that is able to leverage all } \\
\text { these resources and create a tangible/sellable working product/offering will } \\
\text { become pipeline to the suitable RTP Incubators. In some extreme cases, if } \\
\text { the team makes exponential progress, they go out of IITM and setup their } \\
\text { own facilities etc. since they already have customer traction and/or have } \\
\text { raised substantial external funding }\end{array}$ \\
\hline \multirow[t]{2}{*}{$\begin{array}{l}\text { Institutional } \\
\text { culture }\end{array}$} & $\begin{array}{l}\text { NCL Pune: The culture at NCL and in turn the Venture Center is declared } \\
\text { as a collective, and principle-centered. Since it is funded by the Central } \\
\text { government, there is high regard for integrity and vision to contribute to } \\
\text { the national missions where NCL's focus areas can help typically in the } \\
\text { life-science area. The Lab generated about USD } 3 \text { million + in 2012-13, } \\
\text { while patenting at about } 100 \text { in a year (as of 2014). } \\
\text { The Venture Center is located within a technology-intensive Pune cluster } \\
\text { with the local networks, to this end the partnership with local } \\
\text { entrepreneurs community and industry and entrepreneurs is taken seriously } \\
\text { and programs are devised for encouraging interaction and relationship } \\
\text { building. Mumbai, the financial capital of India which is also home to a } \\
\text { significant number of startups and VC firms in India is about just a couple } \\
\text { of hours of drive from Pune. }\end{array}$ \\
\hline & $\begin{array}{l}\text { IIT M:The culture of IITM emphasizes research and innovation. IITM has } \\
\text { one of the best environments to pursue academic research. It is the leading } \\
\text { engineering university in the country as per National Institutional Ranking }\end{array}$ \\
\hline
\end{tabular}




\begin{tabular}{|c|c|}
\hline & $\begin{array}{l}\text { Framework ranking } 2017 / 18 \text {. IITM faculty at any point in time manage } \\
\text { between } 250 \text { - } 350 \text { research and consultancy projects worth about USD } 43 \\
\text { million + annually (NIRF, 2017). } \\
\text { IITM is the leader from academia in the local ecosystem - and is actively } \\
\text { engaging all other players of the entrepreneurial ecosystem. MNCs are } \\
\text { provided infrastructure and technical manpower support if they establish } \\
\text { their labs in the Research Technology Park (RTP). The RTP provides these } \\
\text { facilities at subsidized charges. MNCs work with the faculty and startups } \\
\text { in these incubators and co-develop solutions that have commercial } \\
\text { potential. IITM has established strong and sustained relationships with } \\
\text { various Government departments (Centre and State level). This allows } \\
\text { IITM to enable early adopter access to new product offerings that have } \\
\text { large societal impact. Further, initial seed funding support is also } \\
\text { facilitated by partnership through these Government departments. IITM } \\
\text { Alumni are playing a good role in mentoring the startups. Thus, all the key } \\
\text { stakeholders that are critical to the startup ecosystem are facilitated by } \\
\text { IITM. }\end{array}$ \\
\hline $\begin{array}{l}\text { Number and } \\
\text { strength of } \\
\text { partnerships, } \\
\text { Board } \\
\text { Experience, } \\
\text { Complimentary } \\
\text { value added } \\
\text { services, } \\
\text { partner/investor } \\
\text { connects }\end{array}$ & $\begin{array}{l}\text { NCL Pune: The network of the incubator board and incubator manager in } \\
\text { catering to the needs of startups can also be considered as a key resources } \\
\text { especially for raising capital and building strategic customer relationships. } \\
\text { Alumni networks exist at group level within labs, we did not see large } \\
\text { scale university level alumni forums or interactions. }\end{array}$ \\
\hline
\end{tabular}




\begin{tabular}{|c|c|}
\hline & $\begin{array}{l}\text { of IIT Madras are nominated to help facilitate small informal meetings } \\
\text { with resource persons. However, the faculty do not play a proactive role to } \\
\text { enable networks. Help is provided on a need basis, by requests from } \\
\text { student teams. } \\
\text { The program has a structured mechanism to help incumbent teams with } \\
\text { access to mentors (Business and Technical). These mentors open up access } \\
\text { to their networks and enable the transformation of this idea into a formal } \\
\text { startup, with clearly identified target market segment and technology } \\
\text { components. } \\
\text { The pre-incubation structure also leverages the Alumni network. They } \\
\text { have funded USD } 150000 \text { for CFI, apart from being available as mentors } \\
\text { to students teams. }\end{array}$ \\
\hline \multirow{2}{*}{$\begin{array}{l}\text { Availability of } \\
\text { investors and } \\
\text { investment } \\
\text { capital, Strength } \\
\text { of company } \\
\text { formation/emer } \\
\text { gence at region } \\
\text { level }\end{array}$} & $\begin{array}{l}\text { NCL Pune: Financial resources include majorly grants and support for } \\
\text { entrepreneurship that is provisioned through various institutional } \\
\text { mechanisms of the government, specifically from the Department of } \\
\text { Biotechnology. The stage at which such government grants can be drawn } \\
\text { are typically early stage in the lifecycle of the startup and are in the range } \\
\text { of USD } 5000 \text { to } 80000 \text {. }\end{array}$ \\
\hline & $\begin{array}{l}\text { IITM: No external financial commitment is made to the student teams at } \\
\text { CFI. They need to work on their own, meet their own planned milestones. } \\
\text { If they do meet the milestones, then, they can pitch for formal } \\
\text { pre-incubation. If the idea being worked on is towards participation to a } \\
\text { worldwide contest, then multiple teams will submit their pitch, and the } \\
\text { final selected one will get some funding ( } 1 \mathrm{~K}-2 \mathrm{~K} \text { USD) to ensure its entry } \\
\text { representing IIT Madras. } \\
\text { Each team selected at NIRMAAN is provided between USD } 2000 \text { to } 7000 \\
\text { of finances for a period of about } 1 \text { year to } 18 \text { months. }\end{array}$ \\
\hline
\end{tabular}


Having described how the two successful incubators in India, NCL and IIT Madras enable in opportunity recognition, we perform a comparative analysis of the two universities.

Table 4: Metrics for comparing the two pre-incubation environments at NCL and IITM

(Data sourced from respective university web pages)

\begin{tabular}{|c|c|c|}
\hline Resource Factors & National Chemical Laboratory Pune & $\begin{array}{l}\text { Indian Institute of Technology } \\
\text { Madras }\end{array}$ \\
\hline Number of Startups supported & $\begin{array}{l}51 \text { ventures currently (16 are in } \\
\text { pre-incubation stage as of } 1 \text { August } \\
2018 \text { ) } \\
290 \text { ventures ( } 183 \text { participated in } \\
\text { pre-incubation or associate incubatee } \\
\text { programs cumulatively since inception) }\end{array}$ & $\begin{array}{l}154 \text { ventures currently (including } 52 \\
\text { from sister incubators as of August } \\
2018 \text { ) } \\
\text { More than } 300 \text { in pre-incubation stages }\end{array}$ \\
\hline Branding & $\begin{array}{l}\text { The startups are branded as a } \\
\text { government grant award winner }\end{array}$ & "IIT Madras Incubated Startup", \\
\hline Funding Private & $\begin{array}{l}\text { Industry contributions via Corporate } \\
\text { Social Responsibility route and } \\
\text { Venture capital funding }\end{array}$ & $\begin{array}{l}\text { Industry contributions via Corporate } \\
\text { Social Responsibility route and } \\
\text { Venture capital funding }\end{array}$ \\
\hline Funding Government and Institutional & $\begin{array}{l}\text { Department of Science and Technology, } \\
\text { Department of Biotechnology, Ministry } \\
\text { of Small and Medium Enterprises are } \\
\text { made funds available even for early } \\
\text { stage ventures and developing POC } \\
\text { through the Venture Center mediation } \\
\text { and the government specified } \\
\text { application process }\end{array}$ & $\begin{array}{l}\text { IIT M Startup fund, Grants across } \\
\text { NSTEDB, DBT among others } \\
\text { POC fund }\end{array}$ \\
\hline Patenting by university (filed in India) & $\begin{array}{l}\text { 2012: } 86 ; \\
\text { 2013:173; } \\
\text { 2014: } 101\end{array}$ & 2014-16: 395 \\
\hline
\end{tabular}




\begin{tabular}{|c|c|c|}
\hline Publications by university & $\begin{array}{l}\text { 2013: } 447 \\
\text { 2014:540; } \\
\text { 2015:541 }\end{array}$ & 2014-2016: 5253 (Web of Science) \\
\hline Scientific staff & 200+ with $\mathrm{PhD}$ & $550+$ scientific staff with $\mathrm{PhD}$ \\
\hline $\begin{array}{l}\text { Pre-incubation support centers / } \\
\text { programs }\end{array}$ & $\begin{array}{l}\text { Ignite Program } \\
\text { Kick start program } \\
\text { POC program }\end{array}$ & $\begin{array}{l}\text { Center for Innovation } \\
\text { Nirmaan } \\
\text { Informal pre-incubation support }\end{array}$ \\
\hline Research Centers & 6 research centers & 5 research centers \\
\hline Specialization fields & $\begin{array}{l}6 \text { departments and } 5 \text { centers of } \\
\text { excellence }\end{array}$ & 16 departments and 100 laboratories \\
\hline Industry Interface & $\begin{array}{l}\text { The venture center specifically has a } \\
\text { program targeting corporates through } \\
\text { Softlanding program for corporate } \\
\text { venturing and research, this in turn } \\
\text { leads to collaboration with industry. }\end{array}$ & $\begin{array}{l}\text { Collaboration with various departments } \\
\text { and IIT M as a whole, through setting } \\
\text { up research centers in the research park }\end{array}$ \\
\hline
\end{tabular}

The case studies reveal that IITM programs are more student focused whereas NCL also involves entrepreneurs outside of the research lab as well. Both universities have the presence of a critical mass of research output which possibly feeds into ideation for start-ups. For IITM, the alumni networks have been critical, for NCL the connection with the government departments have been vital. Since the incubators in these two universities are specialized in their respective domains, it enables them to offer focussed start-up support. Both are located within geographical areas with strong entrepreneurial ecosystems. Above all, both have distinct programs and processes right at the pre-incubation phase that enable better opportunity recognition. This can further be seen through the lens of "embeddedness" where the entrepreneur is situated in the socio-economic context of the university and the local economy that could potentially use the new product and service (Jack, S. L., \& Anderson, A. R. 2002). Thus both recognition and realization of the opportunity is contingent upon the entrepreneurs conditioning and embeddedness in the institutional context. Incubators' role in mediating opportunity recognition can be further 
strengthened by the existence of pre-incubation programs especially when ideas are still being validated socially (Cooper, S., \& Park, J. 2008).

The conversion of resources into capabilities is evident during the early stages of the startup development when entrepreneurial teams are building new products/services. Prospective entrepreneurs utilize the pre-incubation programs at the universities to test the waters on new products/services and business viability/feasibility. Thus pre-cursor programs and schemes provide ways in which entrepreneurs can reduce risks during the early stages while building valuable capabilities through product/service development. universities are not challenging the traditional job/placement programs, but provide options to defer placements allowing and encouraging risk taking among students to become entrepreneurs. Such encouragement has taken the form of course credits that can be earned while building products at the pre-incubation support stages.

Although, the forms of such pre-incubation support are varied across both NCL Pune and IIT Madras, we observe certain commonalities. Firstly, there exists safe-fail product development experience whether through student projects in clubs or as continuation of their research work utilizing the university infrastructure. Secondly, as the entrepreneur progresses in his capability of product development, the same safe-fail approach can be cascaded to the venture itself to figure out the viability of the product and venture and test the scalability of the venture's business model. If such risk taking is encouraged formally by the university itself, either through providing credits or allowing to enroll for targeted programs with specific outcomes, the likelihood of opportunity recognition increases. In turn such formalization helps feeding of these technology intensive startups into incubators located in the same environment for further venture support.

\section{Implications for Practice}

The current pre-incubation support system as seen across the country is insufficient in many ways. Although the number of incubators within academic environments have grown by leaps 
and bounds over the past decade, only a few among them may be regarded as truly operational (MSME, 2013). This paper assesses the pre-incubation level processes of two highly successful academic incubators in India viz. NCL Pune and IIT Madras. These incubators were chosen for the study as the same have produced disproportionately high numbers of startups over the recent past. Based on our analysis, we arrived at a few important conclusions.

It is important to understand that the academic support with respect to product development and strategic decision-making for any entrepreneur is a process that starts much earlier before the formal venture incorporation. In fact, the pre-incubation phase is the most critical juncture for opportunity recognition. The mentoring and guidance, intellectual and financial support and above all the hands-on experience, received during the pre-incubation phase is critical in terms of impacting the entrepreneur's attitude towards venture failure.

This study also reveals that it is important to have a continuity of processes that seamlessly feed in from one stage of the venture to another. Further this process of opportunity recognition needs be iterative, before the entrepreneur decides to pursue one single venture idea. In case of most incubators, the specialized phase-wise guidance is lacking. The university-level policies that result in seamless transition across venture phases is also missing. It must be understood that any venture cannot be incubated on a stand-alone basis, rather there is a need for contiguous links in terms of routines and processes with the pre-incubation and post-incubation phases.

Based on the study, we can state that entrepreneurial support system environments cannot function as a single organization that restricts itself to mere provisioning of resources. Without considering the complex nature of pre-venture interaction and other activities that the entrepreneurs need to experience, most incubators will simply continue to be "real-estate" organizations with no real impact both on technology and developmental outcomes.

This study leads to several implications for incubators and the government's policies in the context of incubators. Firstly, incubators need to provide continuity in the technology development process from the point of idea generation to opportunity recognition to prototype 
development. Moreover, the incubators' linkages to the developments in the host university's research output have to be strengthened. Further, the policy makers who fund incubators need to evaluate academic incubators based on not just input metrics but also on developmental outcomes of the startup ideas and the product portfolio. The scalability of specific pre-incubation programs that enable better developmental outcomes need to be examined in detail for assessing their replicability across the country in different academic, cultural and organizational settings. 


\section{References}

Aerts, K., Matthyssens, P., and Vandenbempt, K. (2007). Critical role and screening practices of European business incubators. Technovation, 27(5), 254-267.

Acs, Z. J., Audretsch, D. B., and Lehmann, E. E. (2013). The knowledge spillover theory of entrepreneurship. Small Business Economics, 41(4), 757-774.

Alavi, M., and Leidner, D. E. (2001). Knowledge management and knowledge management systems: Conceptual foundations and research issues. MIS quarterly, 107-136.

Amit, R., and Schoemaker, P. J. (1993). Strategic assets and organizational rent. Strategic management journal, 14(1), 33-46.

Arenius, P., and De Clercq, D. (2005). A network-based approach on opportunity recognition. Small business economics, 24(3), 249-265.

Azoulay, P., Ding, W., and Stuart, T. (2007). The determinants of faculty patenting behavior: Demographics or opportunities?. Journal of economic behavior and organization, 63(4), 599-623.

Bala Subrahmanya MH (2017) HOW DID BANGALORE EMERGE AS A GLOBAL HUB OF TECH START-UPS IN INDIA? ENTREPRENEURIAL ECOSYSTEM EVOLUTION, STRUCTURE AND ROLE. J Dev Entrep 1750006 . doi: $10.1142 / \mathrm{S} 1084946717500066$

Barney, J. (1991). Firm resources and sustained competitive advantage. Journal of management, 17(1), 99-120. 
Bergek, A., and Norrman, C. (2008). Incubator best practice: A framework. Technovation, 28(1-2), 20-28.

Bok, D. (2009). Universities in the marketplace: The commercialization of higher education (Vol. 39). Princeton University Press.

Bøllingtoft, A., and Ulhøi, J. P. (2005). The networked business incubator-leveraging entrepreneurial agency? Journal of business venturing, 20(2), 265-290.

Bowen HK (2015) The Langer Lab: Commercializing Science. 1-30 Retrieved from: https://www.hbs.edu/faculty/Pages/item.aspx?num=31592

Bruton, G. D., Ahlstrom, D., and Li, H. L. (2010). Institutional theory and entrepreneurship: where are we now and where do we need to move in the future?. Entrepreneurship theory and practice, 34(3), 421-440.

Carpenter, R. E., and Petersen, B. C. (2002). Is the growth of small firms constrained by internal finance?. Review of Economics and statistics, 84(2), 298-309.

Chan, K. F., \& Lau, T. (2005). Assessing technology incubator programs in the science park: the good, the bad and the ugly. Technovation, 25(10), 1215-1228.

Chandra, A., and Fealey, T. (2009). BUSINESS INCUBATION IN THE UNITED STATES, CHINA AND BRAZIL: A COMPARISON OF ROLE OF GOVERNMENT, INCUBATOR FUNDING AND FINANCIAL SERVICES. International Journal of Entrepreneurship, 13. 
Cook, S. D., and Brown, J. S. (1999). Bridging epistemologies: The generative dance between organizational knowledge and organizational knowing. Organization science, 10(4), 381-400.

Cooper, S. Y., \& Park, J. S. (2008). The impact ofincubator'organizations on opportunity recognition and technology innovation in new, entrepreneurial high-technology ventures. International Small Business Journal, 26(1), 27-56.

Cooper, A. C., and Yin, X. (2005). Entrepreneurial networks. The Blackwell encyclopaedia of entrepreneurship, 98-100.

Costa-David, J., Malan, J., and Lalkaka, R. (2002, April). Improving business incubator performance through benchmarking and evaluation: lessons learned from Europe. In 16th international conference on business incubation. National Business Incubation Association, Toronto, Canada (Vol. 28).

DIPP (2016) Department of Industrial Promotion and Policy, Startup India Action Plan 2016 http://dipp.nic.in/programmes-and-schemes/industrial-promotion/startup-india

DST (2013) Department of Science and Technology STI Policy Retrieved from: http://www.dst.gov.in/sites/default/files/STI\%20Policy\%202013-English.pdf

DST (2016) Annual Report 2015-16 Retrieved from: http://www.dst.gov.in/about-us/annual-reports

Eisenhardt, K. M., and Martin, J. A. (2000). Dynamic capabilities: what are they?. Strategic management journal, 21(10-11), 1105-1121. 
Etzkowitz H (2002) Incubation of incubators: innovation as a triple helix of university-industry-government networks. Sci Public Policy 29:115-128 . doi: 0302-3427/02/020115-14

Fini, R., Grimaldi, R., Santoni, S., and Sobrero, M. (2011). Complements or substitutes? The role of universities and local context in supporting the creation of academic spin-offs. Research Policy, 40(8), 1113-1127.

Freeman J, Richard D, Miller JC, et al (1983) The Liability of Newness : Age Dependence in Organizational Death Rates Author ( s ): John Freeman, Glenn R . Carroll and Michael T . Hannan Published by: American Sociological Association Stable URL: http://www.jstor.org/stable/2094928 JSTOR is a not-. Am Sociol Rev 48:692-710

Friedman, J., and Silberman, J. (2003). University technology transfer: do incentives, management, and location matter?. The Journal of Technology Transfer, 28(1), 17-30.

Gibson, C., and Vermeulen, F. (2003). A healthy divide: Subgroups as a stimulus for team learning behavior. Administrative Science Quarterly, 48(2), 202-239.

Gompers, P., and Lerner, J. (2001). The venture capital revolution. Journal of economic perspectives, 15(2), 145-168.

Hayter, C. S. (2016). Constraining entrepreneurial development: A knowledge-based view of social networks among academic entrepreneurs. Research Policy, 45(2), 475-490. 
Heirman, A., and Clarysse, B. (2004). How and why do research-based start-ups differ at founding? A resource-based configurational perspective. The Journal of Technology Transfer, 29(3-4), 247-268.

Huang, Y., and Khanna, T. (2003). Can India overtake china?. Foreign Policy, 137(July-August), 74-81.

Jack, S. L., \& Anderson, A. R. (2002). The effects of embeddedness on the entrepreneurial process. Journal of business Venturing, 17(5), 467-487.

Joshi (2015), Economics Of Venture Capital Industry In India: An Analysis Of The Macro Ecosystem And Micro Decision Making, Unpublished thesis at Indian Institute of Science, Bangalore

Joshi, K., and Satyanarayana, K. (2014). What Ecosystem Factors Impact the Growth of High-Tech Start-ups in India? Asian Journal of Innovation and Policy, 3(2).

Klepper, S. (2007). Disagreements, spinoffs, and the evolution of Detroit as the capital of the US automobile industry. Management Science, 53(4), 616-631.

Kogut, B., and Zander, U. (1992). Knowledge of the firm, combinative capabilities, and the replication of technology. Organization science, 3(3), 383-397.

Larson, A.,and Starr, J. A. (1993). A network model of organization formation. Entrepreneurship theory and practice, 17(2), 5-15.

Leonard-Barton, D. (1995). Wellspring of knowledge. Harvard Business School Press, Boston, MA. 
Lockett, A., Siegel, D., Wright, M., and Ensley, M. D. (2005). The creation of spin-off firms at public research institutions: Managerial and policy implications. Research policy, 34(7), 981-993.

Löfsten H, Lindelöf P (2002) Science Parks and the growth of new technology based firms academic industry links, innovation and markets. Res Policy 31:859-876

Lucas Jr, H. C., and Goh, J. M. (2009). Disruptive technology: How Kodak missed the digital photography revolution. The Journal of Strategic Information Systems, $18(1), 46-55$.

Lundvall, B. A. (2007). National innovation systems-analytical concept and development tool. Industry and innovation, 14(1), 95-119.

McAdam M, McAdam R (2008) High tech start-ups in University Science Park incubators: The relationship between the start-up's lifecycle progression and use of the incubator's resources. Technovation 28:277-290 . doi: 10.1016/j.technovation.2007.07.012

McGrath, R. G., and MacMillan, I. C. (2000). Assessing technology projects using real options reasoning. Research-Technology Management, 43(4), 35-49.

Mian, S. A. (1997). Assessing and managing the university technology business incubator: an integrative framework. Journal of business venturing, 12(4), 251-285.

Mian S, Lamine W, Fayolle A (2016) Technology Business Incubation: An overview of the state of knowledge. Technovation 50-51:1-12 doi:10.1016/j.technovation.2016.02.005 
MSME, (Ministry of Micro, Small and Medium Enterprises (2013). Recommendations of the Inter- Ministerial Committee for Accelerating Manufacturing in Micro, Small and Medium Enterprises Sector. New Delhi, India: http://msme.gov.in/

Moray, N., and Clarysse, B. (2005). Institutional change and resource endowments to science-based entrepreneurial firms. Research Policy, 34(7), 1010-1027.

Mosey S, Wright M (2007) From human capital to social capital: A longitudinal study of technology-based academic entrepreneurs. Entrep Theory Pract 31:909-935 . doi:10.1111/j.1540-6520.2007.00203.x

Mowery, D. C., Nelson, R. R., Sampat, B. N., and Ziedonis, A. A. (2001). The growth of patenting and licensing by US universities: an assessment of the effects of the Bayh-Dole act of 1980. Research policy, 30(1), 99-119.

Mustar, P., Renault, M., Colombo, M. G., Piva, E., Fontes, M., Lockett, A., and Moray, N. (2006). Conceptualising the heterogeneity of research-based spin-offs: A multi-dimensional taxonomy. Research policy, 35(2), 289-308.

NCL (2018) Impact Meter. http://venturecenter.co.in/impactdb/reportpv.php. Accessed 12 Jul 2018

NSTEDB (2014) Fuelling Entrepreneurship- The Story of Technology Business Incubation in India Retrieved from: http:/www.nstedb.com/booklet.pdf

NSTEDB (2017) NSTEDB Institutional mechanisms. http://www.nstedb.com/institutional/institutional.htm. Accessed 21 Jul 2018 
Phan PH (2005) Science Parks and Incubators: Observations, Synthesis and Future Science parks and incubators: J Bus Ventur 20:165-182 doi:10.1016/j.jbusvent.2003.12.001

Ramos-Rodriguez, A. R., Medina-Garrido, J. A., Lorenzo-Gómez, J. D., and Ruiz-Navarro, J. (2010). What you know or who you know? The role of intellectual and social capital in opportunity recognition. International Small Business Journal, 28(6), 566-582.

Rasmussen, E., and Borch, O. J. (2010). University capabilities in facilitating entrepreneurship: A longitudinal study of spin-off ventures at mid-range universities. Research policy, 39(5), 602-612.

RBI (2017) Reserve Bank of India - Data Releases PR. In: RBI. https://rbi.org.in/Scripts/Pr_DataRelease.aspx?SectionID=363\&DateFilter=Year. Accessed 21 Jul 2017

Reserve Bank of India (2017) Handbook of Statistics on the Indian Economy 2016-17

Rice, M. P. (2002). Co-production of business assistance in business incubators: an exploratory study. Journal of business venturing, 17(2), 163-187.

Rotger, G. P., Gørtz, M., and Storey, D. J. (2012). Assessing the effectiveness of guided preparation for new venture creation and performance: Theory and practice. Journal of Business Venturing, 27(4), 506-521.

Rubin, T. H., Aas, T. H., and Stead, A. (2015). Knowledge flow in technological business incubators: evidence from Australia and Israel. Technovation, 41, 11-24. 
Scaramuzzi, E. (2002). Incubators in developing countries: Status and development perspectives. Washington DC: The World Bank.

Shane, S. (2000). Prior knowledge and the discovery of entrepreneurial opportunities. Organization science, 11(4), 448-469.

Shane, S., and Cable, D. (2002). Network ties, reputation, and the financing of new ventures. Management science, 48(3), 364-381.

Solesvik, M. Z., and Westhead, P. (2010). Partner selection for strategic alliances: case study insights from the maritime industry. Industrial Management and Data Systems, 110(6), 841-860.

Somsuk, N., Wonglimpiyarat, J.,and Laosirihongthong, T. (2012). Technology business incubators and industrial development: resource-based view. Industrial Management and Data Systems, 112(2), 245-267.

Subrahmanya, M. B. (2017). Comparing the Entrepreneurial Ecosystems for Technology Startups in Bangalore and Hyderabad, India. Technology Innovation Management Review, 7(7).

Tang, M., Baskaran, A., Pancholi, J., and Lu, Y. (2013). Technology business incubators in China and India: A comparative analysis. Journal of Global Information Technology Management, 16(2), 33-58.

Teece, D. J., Pisano, G., and Shuen, A. (1997). Dynamic capabilities and strategic management. Strategic management journal, 18(7), 509-533.

Ulrich, K. T., and Eppinger, S. D. (2000). Product design and manufacturing. 
Van Weele, M., van Rijnsoever, F. J., and Nauta, F. (2017). You can\&\#39;t always get what you want: How entrepreneur's perceived resource needs affect the incubator\&\#39;s assertiveness. Technovation, 59, 18-33.

Venture Intelligence (2014). Database on Private Company Financials, Transactions \& Valuations for India. http://www.ventureintelligence.com

Visintin, F., and Pittino, D. (2014). Founding team composition and early performance of university—Based spin-off companies. Technovation, 34(1), 31-43.

Vohora, A., Wright, M., and Lockett, A. (2004). Critical junctures in the development of university high-tech spinout companies. Research policy, 33(1), 147-175.

Westhead, P., and Storey, D. J. (1997). Financial constraints on the growth of high technology small firms in the United Kingdom. Applied Financial Economics, 7(2), 197-201.

Westhead, P., Ucbasaran, D., \& Wright, M. (2009). Information search and opportunity identification: The importance of prior business ownership experience. International Small Business Journal, 27(6), 659-680.

World Intellectual Property Organization (2017) World Intellectual Property Report 2017: Intangible Capital in Global Value Chains

Zahra, S. A., and Nielsen, A. P. (2002). Sources of capabilities, integration and technology commercialization. Strategic Management Journal, 23(5), 377-398. 
Zahra, S. A., Van de Velde, E., and Larraneta, B. (2007). Knowledge conversion capability and the performance of corporate and university spin-offs. Industrial and Corporate Change, 16(4), 569-608. 